\title{
Atrial natriuretic peptide levels in the sleep apnoea/hypopnoea syndrome
}

\author{
Tom W Mackay, Michael F Fitzpatrick, Stephen Freestone, Michael R Lee, \\ Neil J Douglas
}

\begin{abstract}
Background - Patients with the sleep apnoea/hypopnoea syndrome have increased salt and water excretion at night which has been reported to be associated with an increase in plasma levels of atrial natriuretic peptide (ANP). A study was performed to determine whether any rise in plasma ANP levels was related to nocturnal hypoxaemia.
\end{abstract}

Methods - Nine patients with sleep apnoeal hypopnoea syndrome were studied on two nights, one breathing air and the other $28 \%$ oxygen, the order being randomised. Venous levels of ANP, aldosterone, and renin activity were measured.

Results - No decrease in plasma ANP levels on oxygen was seen, and, indeed, there was no evidence of an overnight increase in ANP levels.

Conclusion - Oxygen therapy does not diminish nocturnal plasma ANP levels in patients with sleep apnoea/hypopnoea syndrome.

(Thorax 1994;49:920-921)

Unit

$S$ Freestone

M R Lee

Department of

Medicine (RIE),

University of

Edinburgh, Edinburgh

EH10 5SB, UK

Reprint requests to:

Dr N J Douglas.

Received 30 September 1993

Returned to authors

18 January 1994

Revised version received

12 April 1994

Accepted for publication

9 May 1994

Table 1 Comparison of sleep and breathing during nights on air and oxygen

\begin{tabular}{lccc}
\hline & Night on air & $\begin{array}{l}\text { Night on } \\
\text { supplemental } \\
\text { oxygen }\end{array}$ & $p$ \\
\hline Non-REM sleep: & $72(14)$ & $59(15)$ & $>0.2$ \\
$\quad$ Apnoeas +hypopnoeas (A+H)/hour & $21(3)$ & $22(2)$ & $>0.5$ \\
$\quad$ Mean duration of A+H (seconds) & $89(13)$ & $71(10)$ & 0.02 \\
$\quad$ Arousals/hour & & & \\
REM sleep & $61(13)$ & $33(12)$ & $>0.1$ \\
$\quad$ Apnoeas +hypopnoeas (A+H)/hour & $27(7)$ & $32(12)$ & $>0.5$ \\
Mean duration of A+H (seconds) & $44(9)$ & $45(11)$ & $>0.9$ \\
$\quad$ Arousals/hour & $226(25)$ & $171(22)$ & $>0.05$ \\
Total sleep time (min) & $192(21)$ & $157(20)$ & $>0.2$ \\
Non-REM sleep & $34(10)$ & $14(5)$ & 0.01 \\
REM sleep & & & \\
\hline
\end{tabular}

Values are mean (SE)

is reversed sure (CPAP) therapy. ${ }^{24}$ The nocturia has been associated with increased plasma levels of atrial natriuretic peptide (ANP) ${ }^{56}$ which are corrected with CPAP. ${ }^{5}$ Causes suggested for the rise in ANP include intrathoracic pressure swings, haemodynamic sequelae of arousal, or pulmonary hypertension related to hypoxaemic episodes. We have investigated this last hypothesis as plasma levels of ANP in other situations relate to hypoxaemia. ${ }^{78}$

\section{Methods}

Nine men of mean (SE) age 52 (5) years with the sleep apnoea/hypopnoea syndrome (median 52 (range 23-115) apnoeas + hypopnoeas/hour) spent two consecutive nights undergoing our standard polysomnographic recordings, ${ }^{9}$ arousals being defined as a 1.5 second return of alpha or theta rhythm with an increase in EMG, however brief. ${ }^{10}$ On both nights they breathed through a mask, on one night receiving air and the other $28 \%$ oxygen. An arterial sample was drawn 30 minutes after the mask was fitted. An indwelling venous catheter was sited and the subjects lay for 30 minutes before baseline samples were drawn. Four further samples were taken during nonREM sleep at 30 minute intervals and up to three during REM sleep at 10 minute intervals. Levels of $\mathrm{ANP}^{11}$ and plasma renin activity ${ }^{1112}$ were assayed by standard techniques and plasma aldosterone levels by radioimmunoassay (Euro Diagnostic Products Ltd, Llanberis, UK). Urine levels of dopamine were measured by high performance liquid chromatography following standard extraction. ${ }^{13}$ Statistical analysis was by the Student's $t$ test.

\section{Results}

Oxygen therapy improved the presleep arterial oxygen tension (16 (1) $\mathrm{kPa}$ on oxygen, 10 (1) $\mathrm{kPa}$ on air; $\mathrm{p}=0.001)$ without changing arterial $\mathrm{PCO}_{2}$ and also raised the lowest nocturnal oxygen saturation (median $81 \%$ (range 13-95\%) on oxygen; $55 \%(0-87 \%)$ on air; $\mathrm{p}<0.02)$. There was no difference in the number or duration of apnoeas or hypopnoeas on the two nights, but there was a slight increase in the frequency of arousal from non-REM sleep during the night on air (table 1).

There were no significant differences in presleep levels of ANP, aldosterone, or plasma renin activity between the two nights, nor any differences in the average levels obtained during sleep. There was, however, a weakly significant increase $(p<0.05)$ in ANP levels when oxygen 
Table 2 Comparison of venous blood levels of ANP, aldosterone and plasma renin activity (PRA) and urinary dopamine levels during nights on air and oxygen

\begin{tabular}{|c|c|c|c|}
\hline & Night on air & $\begin{array}{l}\text { Night on } \\
\text { supplemental } \\
\text { oxygen }\end{array}$ & $p$ \\
\hline $\begin{array}{l}\text { ANP }(\mathrm{pg} / \mathrm{ml}) \\
\text { Pre-sleep } \\
\text { Non-REM sleep } \\
\text { REM sleep }\end{array}$ & $\begin{array}{l}81(29) \\
75(10) \\
95(12)\end{array}$ & $\begin{array}{l}88(30) \\
95(11) \\
78(15)\end{array}$ & $\begin{array}{l}>0.9 \\
<0.05 \\
>0.6\end{array}$ \\
\hline $\begin{array}{l}\text { Aldosterone }(\mathrm{pg} / \mathrm{ml}) \\
\text { Pre-sleep } \\
\text { Non-REM sleep } \\
\text { REM sleep }\end{array}$ & $\begin{array}{l}326(127) \\
225(39) \\
235(39)\end{array}$ & $\begin{array}{l}328(137) \\
217(44) \\
265(97)\end{array}$ & $\begin{array}{l}>0.9 \\
>0.9 \\
>0.6\end{array}$ \\
\hline $\begin{array}{l}\text { PRA (ng AngI/ml/h) } \\
\text { Pre-sleep } \\
\text { Non-REM sleep } \\
\text { REM sleep }\end{array}$ & $\begin{array}{l}4.0(1 \cdot 2) \\
2 \cdot 6(0 \cdot 3) \\
1 \cdot 8(0 \cdot 4)\end{array}$ & $\begin{array}{l}3.6(1.2) \\
2.7(0.5) \\
1.9(0.4)\end{array}$ & $\begin{array}{l}>0.2 \\
>0.2 \\
>0.8\end{array}$ \\
\hline $\begin{array}{l}\text { Urinary dopamine (nmol) } \\
2300-0400 \text { hours }\end{array}$ & $656(146)$ & $633(66)$ & $>0.8$ \\
\hline
\end{tabular}

Laboratory normal ranges: ANP, $10-110 \mathrm{pg} / \mathrm{ml}$; aldosterone, $10-160 \mathrm{pg} / \mathrm{ml}$; PRA, $0 \cdot 1-3 \cdot 1 \mathrm{ng}$ AngI $\mathrm{Laboratory} \mathrm{normal} \mathrm{ranges:} \mathrm{ANP} 10-110 \mathrm{pg} / \mathrm{ml}$; aldosterone, $10-1$
$\mathrm{ml}$ (supine); urinary dopamine, $650-2280 \mathrm{nmol} / 24$ hours.

was given compared with the night on air. There was no difference in urinary dopamine levels between the two nights (table 2).

\section{Discussion}

This study shows no diminution in plasma ANP levels with oxygen therapy. Indeed, post hoc analysis showed no significant increase in ANP levels during sleep. This latter observation is compatible with a report by Partinen et $a l^{8}$ in a group of 17 snorers, nine with sleep apnoea/ hypopnoea syndrome. The decreases in ANP levels with CPAP reported in some, ${ }^{514}$ but not all, ${ }^{1516}$ studies may be due to either normalisation of intrathoracic pressure or improvements in sleep quality.

The marginal elevation in plasma levels of ANP in non-REM sleep during the night on oxygen is of dubious significance, may reflect the number of comparisons made, and cannot be readily explained by changes in breathing or sleep pattern.

The high baseline aldosterone levels and plasma renin activity were due to three patients receiving diuretics. However, these patients were acting as their own controls for the a priori comparison of air against oxygen which is not invalidated by this therapy.

1 Guilleminault C, Tilkian A, Dement WC. The sleep apnea syndrome. Annu Rev Med 1976;2:465-84.

2 Warley ARH, Stradling JR. Abnormal diurnal variation in salt and water excretion in patients with obstructive sleep apnoea. Clin Sci 1988;74:183-5.

3 Whyte KF, Allen MB, Jeffrey AA, Gould GA, Douglas NJ. The clinical features of the sleep apnoea/hypopnoea syndrome. $Q \mathcal{F}$ Med 1989;72:659-66.

4 Krieger J, Imbs JL, Schmidt M, Kurtz D. Renal function in patients with obstructive sleep apnea. Effect of nasa continuous positive airway pressure. Arch Intern Med 1988 148:1337-40.

5 Krieger J, Laks L, Wilcox I, Grunstein RR, Costas LJV, McDougall JG, et al. Atrial natriuretic peptide release during sleep in patients with obstructive sleep apnoea before and during treatment with nasal continuous positive airway pressure. Clin Sci 1989;77:407-11.

6 Krieger J, Schmidt M, Sforza E, Lehr L, Imbs JL, Coumaros $\mathrm{G}$, et al. Urinary excretion of guanosine $3^{\prime}: 5^{\prime}$-cyclic monophosphate during sleep in obstructive sleep apnoea patients with and without nasal continuous positive airway pressure treatment. Clin Sci 1989;76:31-7.

7 Krieger J, Follenius M, Sforza E, Brandenberger G, Peter JD. Effects of treatment with nasal continuous positive airway pressure on atrial natriuretic peptide and arginine vasopressin release during sleep in patients with obstructive sleep apnoea. Clin Sci 1991;40:443-9.

8 Partinen M, Telakivi T, Kaukiainen A, Salmi T, Farkkila $\mathrm{M}$, Saijonmaa $\mathrm{O}$, et al. Atrial natriuretic peptide in habitual snorers. Ann Med 1991;23:147-51.

9 Douglas NJ, Thomas S, Jan MA. Clinical value of polysomnography. Lancet 1992;339:347-50.

10 Cheshire K, Engleman H, Deary I, Douglas NJ. Factors inpairing daytime performance in patients with the sleep apnoea/hypopnoea syndrome. Arch Intern Med 1992;152: 538-41.

11 Freestone S, Jeffrey RF, Bonner CV, Lee MR. Effect of lithium on the renal actions of $\boldsymbol{x}$-human atrial natriuretic peptide in normal man. Clin Sci 1990;78:371-5.

12 Haber $E$, Koerner $T$, Page LB, Kliman B, Purnode A. Application of a radioimmunoassay for angiotensin $I$ to the physiologic measurement of plasma renin activity in the physiologic measurement of plasma renin activity in normal hum

13 Anton AH, Sayre DF. The distribution of dopamine and dopa in various animals and a method for their determination and diverse biological material. If Pharmacol Exp Ther 1964;145:326-36.

14 Baruzzi A, Riva R, Cirignotta F, Zucconi M, Cappelli M, Lugaresi E. Atrial natriuretic peptide and catecholamines in obstructive sleep apnea syndrome. Sleep 1991;14:83-6.

15 Warley ARH, Morice A, Stradling JR. Plasma levels of atrial natriuretic peptide (ANP) in obstructive sleep apnoe (OSA). Thorax 1988;43:253P.

16 Lin C-C, Tsan K-W, Lin C-Y. Plasma levels of atrial natriuretic factor in moderate to severe obstructive sleep apnea syndrome. Sleep 1993;16:37-9. 